\title{
Fome e redes comerciais na Bacia Parisiense (séculos VII-XI)
}

\section{Famine and commercial networks in the Parisian Basin ( $7^{\text {th }}-11^{\text {th }}$ centuries)}

Gabriel Rodrigues Sanches Cordeiro ${ }^{1}$

A Alta Idade Média foi entendida pelos historiadores até meados do século XX como um longo período de crise e de declínio, não apenas devido aos múltiplos períodos de fome, mas também por questões econômicas e políticas. Essa interpretação pessimista tem sido contestada nas últimas décadas. Com um panorama menos negativo com relação à economia medieval, também vieram questionamentos a cerca da "veracidade" das crises alimentares, ou pelo menos de seus aspectos mais sombrios. Alguns relatos da fome usam passagens bíblicas como modelo. Isso fez com que alguns historiadores enxergassem as "colheitas falsas" e o canibalismo de sobrevivência como recursos retóricos, pois eram associados com a ação divina, uma punição pelos pecados dos habitantes do reino.

Ao realizar um estudo da fome no início da Idade Média, entramos em contato com a dura realidade fornecida por fontes rarefeitas. Diferente do que se observa para o século XIV em diante, os primeiros séculos da Idade Média distinguem-se pela ausência de documentação precisa acerca da produção, compra, venda e estocagem de alimentos. No lugar de inventários detalhados, ou de séries de preços, temos evidências imprecisas que, no entanto, apontam para a escassez de alimentos em diversos momentos. A análise arqueológica oferece dados fundamentais para a melhor compreensão da fome durante a Alta Idade Média. Nesta apresentação, buscarei analisar os indícios arqueológicos de La Confiserie, localizado em Villiers-le-Bel, usando como pontos de comparação outros dois sítios contemporâneos da bacia parisiense: Les Ruelles e La Chapelle/La Croix Verte.

La Confiserie e Les Ruelles possuem registros arqueológicos diametralmente opostos. No primeiro deles, há o único provável indício encontrado de canibalismo de sobrevivência durante toda a Idade Média, fenômeno descrito treze vezes nas fontes escritas entre os séculos VIII e XI. Em contrapartida, Les Ruelles tem silos muito bem abastecidos e variados. Foram encontrados, indícios de alimentos raros, como faisão e ostras. La Chapelle/La Croix Verte não possui registros tão extremos quanto os outros sítios, mas conta com muitas estruturas relacionadas à produção e à estocagem de alimentos, que foram descritas e analisadas pelos arqueólogos. Além disso, La Chapelle/La Croix Verte pode ser usado como um ponto neutro entre os outros dois sítios por não estar em condições tão extremas quanto eles.

Até o momento, de acordo com o andamento da pesquisa, podemos dizer que há dois pontos principais para esta análise: a proximidade com os habitats aristocráticos e a integração dos sítios com as redes comerciais. La Confiserie era o único sítio que se encontrava isolado delas. De acordo com as evidências alimentares e os resquícios de comércio, a fome não parece ter sido tão abrangente e total quanto os historiadores apontavam no século XX. Ainda que ela fosse uma realidade e seu impacto claro, seus efeitos de distribuem se maneira desigual de acordo com diversos fatores. 
Palavras-chave: fome; arqueologia medieval; abastecimento.

Keywords: hunger; medieval archeology; supply.

1 Graduando em História pela Universidade de São Paulo, bolsista de Iniciação Científica pela Fapesp. 